\title{
ELFINS AND DENSMEN
}

\author{
Geoffrey Grigson \\ (Country Life, 6th Jan, 1977)
}

If you have ever read - and of course Sylvia Townsend Warner has read it - "An Essay of the Nature and Actions of the Subterranean (and, for the most part, Invisible) People, heretofoir going under the name of Elves, Faunes and Fairies, or the lyke', written in 1691 by Robert Kirk, 'Minister at Aberfoill', and published by Andrew Lang as The Secret Commonwealth, you will know that these Other People were not small and airy-fairy; and you will have just an inkling of what to expect from the latest book by that extraordinary veteran, Sylvia Townsend Warner.

Robert Kirk translated the Psalms into Gaelic. Miss Warner translates fantasy into sharp and delightful English, in a collection of stores as unlike Maeterlinck or Midsummer Night's Dream as you can imagine. She is a Dean Swift, a Deaconess Swift, of her various Elfin Kingdoms across Europe from Scotland and Suffolk to Holland, Brittany, Austria and Germany. Like Swift she is undeluded, worldly and sardonic, only genial and lyrical, ungiven to terribilita. Without employing a Gulliver, she takes the lid off the green hills and the other castles of the Elfin Kingdoms, and there they are, these Other People, in lives of a difference which illustrates our own living.

Like Swift, Miss Warner speaks from our world all the time, in a sharp contemporary voice that made these tales at once apt and unexpected contributions to the New Yorker. 
First of all, that business of size, 'It is commonly supposed', she says in one story - 'that fairies, or elfins, are trifling little beings, always on the wing and incapable of dying. This misapprehension has come about because they prefer to live in invisibility - though they can be visible at will, by means of an automatic mechanism rather like the una corda pedal or a gearshift.'

Elfin Kingdoms paralleled human kingdoms. Flying though all elfins had wings - was left to the lower orders: 'In fact they are about four fifths of ordinary human stature, fly or don't fly according to their station in life, and after a lifespan of centuries die like other people - except that as they do not believe in immortality they die unperturbed.'

There you have two innocent examples of the varied way in which Miss Warner achieves delight. She is given to the tickle, the sting, the slap in the tail of a paragraph which translates the bizarre into the familiar - the gearshift for flight; or contrasts elfinity with humanity - no fear of death because for the elfin there is no question of an after-life.

There is a logic in these contrasts. Propound a fantastic situation, and what follows from it unfantastically, realistically, logically? The mode is varied several times in the third and one of the best of the stories, 'Elphenor and Weasel'. Elphenor is a Dutch elfin blown off course into Suffolk, where he is employed in visible shape by Master Blackbone, 'a quack in several arts, including medicine, necromancy, divination and procuring'. Elphenor encounters a green Suffolk elfin of great charm named Weasel (Miss Warner is well aware that although weasels are not very nice - from a rabbit's point of view - they are very beautiful little creatures from our point of view, each with a face like a seal in miniature. Weasels smells like elder-flowers, a bit sexy and over-sweet. Weasel is described, as Elphenor first sees her; and you think Miss Warner is coasting the whimsical. But wait - till the last word:

'She was a very pretty shade of green - a pure delicate tint, such as might have been cast on a white eggshell by the sun shining through the young foliage of a beech tree. Here hair, brows, and lashes were a darker shade; her lashes lay on her 
green cheek like a miniature fern frond. Her teeth were perfectly white. Her skin was so nearly transparent that the blue veins on her wrists and breasts showed through like some exquisitely marbled cheese.' Weasel was like cheese.

There are plenty more contrasts in Weasel. 'Though invisible, she might not be inaudible, and her voice was ringing and assertive as a wren's.' The Weasel who sings like a wren.

Or the habits of this elfin: "They breakfasted on wild strawberries and a hunk of bread he [i.e. Elphenor] had had the presence of mind to take from the bread crock. It was not enough for Weasel, and when they came to a brook she twitched up a handful of minnows and ate them raw.'

That reminds me of a curt throw-away, in another of the stories, about the stealing of human babies who are brought up as pets inside the green hills or other Elfin castles, after a conditioning process analogous to our neutering of tom kittens. Two of these humans, now adult, re-named Morel and Amanita (Miss Warner knows all about fungi, of course), brawl in a smelly, unseemly way in The Queen of the Fairies' bedroom, on May Morning. Soon everything was in order again: 'Morel and Amanita had been strangled and their bodies thrown on the moor as a charity to crows.' Always a surprise.

Back to Elphenor and Weasel. They shack up for winter in a splendid East Anglian church with winged angels down either side of the roof. Elphenor as quack's apprentice 'had learned some facts about the Church of England, one of them that the reigning monarch, symbolically represented as a lion and a unicorn, is worshipped noisily on one day of the week and that for the rest of the week churches are unmolested'. They settle in, and then - 'He woke to the sound of Weasel laughing. Daylight was streaming in, and Weasel was flitting about the roof, laughing at the wooden figures that supported the crossbeams - carved imitations of fairies, twelve feet high, with outstretched turkey wings and gaunt faces, each uglier than the last. So that's what they think we're like, she said, "And look at her!" She pointed to the fairy above the pulpit, struggling with a trumpet.' 
I shall indulge myself and you with one more quotation, from the story of some discontented and discarded Elfins ('One day in early spring the Queen was bitten by a mouse. The result was totally unforeseen' - but that is not the quotation), who are given to philosophy, take to a deserted temple of Aesculapius in Greece, and become the beloved guests of a fat pederastical Turkish bey. This marvellously inventive tale begins:

'Wirre Gedanken was a small Elfin kingdom, never of any importance and now extinct.' In the Austrian section of Countess Morphy's 'Recipes of All Nations', Wirre Gedanken (translated 'Troubled Thoughts') designates a kind of fried bun: but there does not seem to be any historical connection. A beautiful inconsequence. And there's the tone, the weave of these stories, light and serious, sardonic and learned. Miss Warner's judgment is so good, not stopping short, not overdoing it. And her writing is so good.

After reviewing this in the pannage season of literary prizes - for pannage see below - $I$ comment that prizes do not go to such books as Elfin Kingdoms. They go to short-lived, fish-finger packets precisely with a sub-bourgeois taste of cod, flour, bread crumbs and batter. 